\title{
AT VENDE TILBAGE TIL UKENDTE STEDER POSTHUKOMMELSE OG STED HOS
JACOB DAMMAS, JACOB KOFLER OG
MAJA MAGDALENA SWIDERSKA
}

RETURNING TO UNFAMILIAR PLACES. PLACE AND POSTMEMORY IN THE WORKS OF JACOB DAMMAS, JACOB KOFLER, AND MAJA MAGDALENA SWI-

DERSKA I The emigration of three thousand Polish-Jewish citizens to Denmark as a result of the events in March 1968 in Poland has only recently attracted attention from filmmakers and writers in Denmark. Two documentary films and a novel, created within a relatively short period of time, deal with the topic: Jacob Kofler's Statsløs (Stateless), 2004, Jacob Dammas' Kredens (Dresser), 2007, and Maja Magdalena Swiderska's The Border Breaking Bunch, 2008. The authors are all children of refugees and represent second generation in relation to the cultural trauma of exile. The article examines aesthetic approaches developed by the authors as they (re)tell personal stories, which are mediated through various strategies of postmemory (Hirsch 1997). Postmemory is distinguished from memory by a non-indexical relation to the past and a generational distance, and from history by a highly personal approach. However, it is not addressed here as a psychological category. On the contrary, I argue that postmemory can be viewed as both an analytical and a narrative and aesthetic tool. Questions of place and place-related identity are relevant and inseparable from the three authors' creative reimaginings of the cultural and personal trauma. Thus, the article focuses on the concepts of place and postmemory, and their interdependencies in the analysed works. Close readings are combined with theoretical reflection, which allows the objects and theories to illuminate each other.

KEYWORDS I place, postmemory, accented cinema, cultural analysis, 'Eastern Europe'

"Mine forældre er meget stolte af deres tavshed. Det var deres måde at spare de andre, og især deres børn, lidelser på. I denne tavshed har der været overleveret alt ud over en fortælling. Og når man er tavs, kan man jo ikke ændre på tråde i den historie, der skjuler sig bag tavsheden,”

- sagde den jødiske kunstner Bracha L. Ettinger (Pollock), som repræsenterer den såkaldte anden generation efter dem, der oplevede Holocaust.

Når man læser Maja Magdalena Swiderskas roman The Border Breaking Bunch 
(2008) og ser de to dokumentarfilm Kredens ("Skænk”) af Jacob Dammas fra 2007 og Statsløs af Jacob Kofler fra 2004, kan man ikke overse, at der ligger én fælles drift til grund for disse værker: Deres fortællere vil (gen)fortælle den historie, der "skjuler sig" bag deres forældres tavshed. Deres skabere har en tredobbelt, polskjødisk-dansk oprindelse, og alle er født og opvokset i Danmark. Med andre ord repræsenterer de anden generation efter dem, der oplevede den (mere eller mindre) traumatiske erfaring af eksil. De fremstiller samtidig sig selv som den første generation, der fortæller om denne erfaring. Blandt de danske værker fra de sidste cirka tredive år, der repræsenterer forestillinger om 'Østeuropa', ${ }^{\mathrm{I}}$ udgør nævnte værker en særlig gruppe, netop på grund af den tætte og personlige relation, som deres fortællere har i forhold til et øst- eller centraleuropæisk land og dets historie. Som forestilling forstås her et imaginært billede, repræsenteret litterært eller visuelt, af et andet land, kultur eller folk, der samtidig må opfattes i et dynamisk forhold til forestillinger om fortællernes eget hjemland (Beller og Leerssen 342).

Ovennævnte værker er skabt i en kreativ, æstetisk bearbejdning - en kunstnerisk genfortælling - af kunstnernes forestillinger om deres forældres fortiede fortid. Den type kreativ bearbejdning af familiefortid er påpeget af den amerikanske litteraturforsker Marianne Hirsch som et væsentligt aspekt ved det, hun betegner som posthukommelse (postmemory, dvs. memory of memory) (Hirsch). Begrebet betegner hukommelse nedarvet fra de foregående generationer om en i familien fortiet og traumatisk, kollektiv erfaring. Som Hirsch understreger, så er posthukommelse, i modsætning til bukommelse, kendetegnet ved distancen mellem generationer, som tillader en konstruktiv og kreativ bearbejdning af fortiden og de ofte fastfrosne forestillinger nedarvet fra forældrene. ${ }^{2}$ Fra bistorie adskiller den sig ved en dybt personlig relation til de fortidige begivenheder (Hirsch 22). I sine analyser af anden generations æstetiske bearbejdninger af det kollektive - kulturelle (Eyerman 2) - traume (Holocaust), beskriver Hirsch ikke bare den personlige, men også den kulturelle proces af formidling og repræsentation.

Hirsch benytter begrebet postmemory med reference til børn af dem, der overlevede Holocaust. Jeg vælger imidlertid at benytte begrebet bredere og her i forhold til den posthukommelse, der er forbundet med det subjektive perspektiv hos de omtalte kunstnere. Hos Swiderska, Dammas og Kofler kan posthukommelsen betegnes som 'posthukommelse over grænser', og den er sammenflettet med fortællernes nationale identitet, som hos de to første er hybrid 3 og 'suspenderet', 4 kendetegnet

I Anførselstegn omkring ordet 'Østeuropa' skal indikere, at der ikke er tale om et fagligt korrekt begreb. Ordet er alment brugt både i Danmark og andre vestlige lande i stedet for begreber som Centraleuropa eller Centralog Østeuropa, og det kan opfattes som en afspejling af den konstruerede og imaginære dimension ved forestillinger om regionen.

2 Den distance beskriver Ernst Van Alphen som en mangel på "indexical relationship" (et forhold baseret på den direkte/fysiske forbindelse) mellem begivenhed og hukommelse (Van Alphen 486).

3 Hybrid identitet forstås her som et resultat af transkulturelle interaktioner, og som en modsætning til en nationalt homogen identitet (Beller og Leerssen 34I; Ashcroft Io8-III).

4 “Diaspora-tilstanden medfører en 'suspendering' af éns identitet, en position kendetegnet ved at være adskilt fra både sit hjemland og det nye land” (Mazierska og Rascaroli 138). 
ved følelsen af en dobbelt fremmedhed - i forhold til både oprindelsesland og det nye hjemland. Disse forhold påvirker både det, der fortælles om og den måde, man fortæller og bruger sit medium på. Analysen vil derfor fokusere på reprcesentationer af forskellige forestillinger, som de kommer til udtryk gennem litterære og filmiske strategier. Som Hirsch og Irene Kacandes påpeger, så gør distancen, der adskiller den anden og de kommende generationer fra den faktuelle begivenhed (Holocaust), det særligt nødvendigt at fokusere på selve repræsentationen, dvs. strategier og konventioner benyttet i formidlingen af traumet (Hirsch og Kacandes 5).

Min fremgangsmåde i artiklen er interdisciplinær og benytter sig af den kritiskanalytiske strategi, som Mieke Bal betegner cultural analysis. Den kombinerer nærlæsninger af de forskellige objekter - to dokumentarfilm og en roman - med en teoretisk refleksion, hvor begge parter - objekter og teori - kaster lys på hinanden (Bal). Objekter deltager med andre ord aktivt i konstruktionen af de teoretiske synspunkter, som her koncentrerer sig om begreberne postmemory og sted. Jeg har udvalgt disse værker, som alle stammer fra omtrent samme tid og sted, fordi jeg betragter dem som frugtbare udfoldelser af disse begreber. Fokus er imidlertid ikke på en genre eller kunstart, men på begreberne. Den interdisciplinære tilgang, som tager højde for mediernes egenart, hjælper med at belyse begrebernes flersidige aspekter og samtidig værkernes muligheder og begrænsninger.

\section{Fortcellinger med accent - det polske marts 1968 på dansk}

Den kollektive traumatiske erfaring, som står i centrum for Swiderskas roman og de to dokumentarfilm, handler om en gruppe polakker med jødisk oprindelse, hvis skæbner blev påvirket af et grusomt kapitel i antisemitismens historie, som resulterede i en måske lidt glemt episode i polsk-dansk historie. Som følge af indre konflikter i det polske kommunistiske partis ledelse og behovet for en syndebuk, der kunne gøres ansvarlig for studenteroprøret imod det undertrykkende system, blev omkring tyve tusind polske statsborgere af jødisk oprindelse efter uroligheder i marts 1968 tvunget til at forlade Polen. Ved udrejsen fik de et pas, som kun var gyldigt den ene vej - og som fratog dem deres polske statsborgerskab og gjorde dem statsløse. Danmark modtog dengang cirka tre tusind statsløse emigranter, herunder Swiderskas, Dammas' og Koflers forældre. Deres børn - nu alle mellem tredive og fyrre år gamle - fortæller en historie om, hvad deres forældres fordrivelse fra hjemlandet under det kommunistiske regime og flugten til Danmark, inden de selv blev født, har betydet for deres liv, identitet og selvforståelse.

De tre værker har flere fællestræk. For det første bliver statsløshed en symbolsk tilstand. For det andet foretager deres hovedpersoner alle en rejse - både en reel rejse tilbage til forældrenes hjemsted og en mental rejse ind i en projiceret fortid. 5 Netop stederne spiller en central rolle i deres fortællinger - de bliver til posthukommelsens

5 Mental roadmovie, som det hedder det på DR2s hjemmeside om Jacob Koflers film, DRPresse. 22.juni 20II, http://www.dr.dk/DRPresse/Artikler/2004/Io/13/Statsls.htm. 
steder. Derfor vil jeg lægge vægt på relationen mellem posthukommelse og sted i mine analyser. Sted opfattes her som en oplevet, konkret lokalitet, der samtidig er formidlet af "kulturelt og historisk overlejrede billeder og forestillinger" (Ringgaard 3I) - og repræsenteret i værkerne. Sted er med andre ord ikke en tidløs og isoleret dimension, men et knudepunkt af de "fortællinger-indtil-nu” (Ringgaard 93), der har påvirket fortællernes forestillinger.

Billedet af det andet (fortidens) land er i de omtalte værker uadskilleligt fra billedet af det (nutidige) (hjem)land, Danmark. Det synes frugtbart i forhold til de omtalte værker at benytte Mikhail Bakhtins begreb kronotop sådan som filmforskeren Hamid Naficy foreslår det i forhold til første generations eksil- og diaspora-filmmagere (Naficy I52), selvom der typisk findes en betydelig forskel på opfattelsen af hjem- og gæstelandet mellem første og anden generation. Naficy påpeger tre hovedkronotoper, der indgår i forskelligartede indbyrdes relationer: det imaginære hjemlands kronotop, eksillivets (gæstelandets) kronotop og det tredje rums kronotop. Ifølge Naficy er hjemlandets kronotoper oftest 'åbne' (utopiske forestillinger om hjemlandet, ikke overskyggede af nutidens begivenheder), mens eksillandets kronotoper er 'lukkede' (eksil som fængsel, dystopiske forestillinger om nutiden). Det tredje rums kronotop indebærer forestillinger om grænse- og overgangsrum og kan sætte de to andres modsætningsforhold i bevægelse.

Måden, hvorpå Swiderska, Dammas og Kofler bearbejder og sammenstiller forskellige kronotoper, fører til, at man kan betegne deres værker som 'værker med accent'. Dette begreb er et parafraseret lån fra Naficy, som kalder eksilinstruktørernes film for accented cinema, kendetegnet ved en særlig 'accentueret' stil (Naficy Io) på grund af eksilerfaringen. Begrebet betegner også i væsentlig grad den erfaring og stil, som anden generation giver udtryk for i deres bearbejdning af den nedarvede eksilerfaring. Denne erfaring hænger sammen med kunstnernes enten selvvalgte eller påtvungne position ved 'centrums' 'udkant', ${ }^{6}$ både i tematisk, generisk og produktionsmæssig forstand. Denne position skaber en særlig type følsomhed hos dem. De „formodes at være mere udsatte for spændinger relateret til marginalisering og forskel” (Naficy Io). 'Værker med accent' er ofte genremæssige hybrider med en fragmentarisk og åben fortællestruktur; de handler om rejser drevet af en trang til at finde hjem(landet) eller om nomadiske vandringer i verden; de plejer at sammenstille personlige erindringer og den offentlige historie; instruktøren, fortælleren og hovedpersonen smelter sammen i én og samme person.

Både Koflers, Dammas' og Swiderskas værker kan betegnes som 'accentueret', men af mine analyser vil det fremgå, at Dammas' film og Swiderskas roman er kendetegnet ved en særlig høj grad af 'udkantens' erfaring, mens Statsløs ligger tættere på 'centrum'. Koflers optik kan desuden kaldes for nedarvet fra eksilfortællinger,

6 Her skal relationen mellem 'centrum' og 'udkant' ikke forstås som et binært og a priori hierarkisk forhold (det magtfulde centrum modsat den magtesløse udkant). Her drejer det sig rettere om forholdet mellem 'mainstream' og ikke-'mainstream' produktionsvilkår og æstetik, hvor det sidste ofte (men ikke nødvendigvis) bruges til at undergrave det første. Dette forhold kan, men behøver ikke blive værdiladet. 
mens der i Swiderskas og Dammas’ tilfælde er tale om diasporafortællinger. Med Naficys begreber: "i modsætning til flygtninge [exiles], hvis identitet involverer et vertikalt og primært forhold til deres hjemland, er diasporabevidstheden horisontal og orienteret mod flere steder [multisited]" (Naficy I4). Koflers perspektiv kunne beskrives som postexilic, mens Swiderskas og Dammas' som postdiasporic, selvom de alle refererer til én fælles oplevelse og overskrider den enkelte begivenhed ved at række tilbage til Holocaust som en del af deres kulturelle identitet. Præfikset 'post' signalerer forbindelsen til posthukommelsen, men peger også på fortællernes distance til det nuværende diaspora- eller eksilmiljø; de fortæller ud fra det, men samtidig "væk fra diasporaen som skæbne" (Ping Huang I2), dog ikke nødvendigvis i retning mod (det danske) 'centrum'. I denne kontekst er det interessant at nævne, at den jødiske minoritet er (opfattet som) en af de bedst integrerede indvandrergrupper i det danske samfund, ikke mindst den gruppe, der kom til Danmark i kølvandet på begivenhederne i Polen i marts 1968. Dammas' og Swiderskas værker er også i den forstand stemmer fra udkanten. I modsætning til Kofler er de kendetegnet ved en mangel på god integration.

\section{Jacob Dammas: Sted mellem legende og historie}

Jacob Dammas' dokumentariske kortfilm Kredens ("Skænk”), belønnet med flere priser, 7 kan virke indforstået, især hvis man af en dokumentar forventer en forklaring og beskrivelse af de faktuelle eller historiske begivenheder. Den kan betegnes som en kreativ dokumentar og er samtidig et socialt eksperiment. ${ }^{8}$ Kredens er anderledes i forhold til både Koflers Statsløs og andre dokumentarfilm om marts 1968. ${ }^{9}$ For det første ønsker den ikke at fortclle om fortiden - den handler om (post) hukommelse eller rettere, den inkarnerer posthukommelsen, som er uadskillelig fra fortællerens hér og nu. For det andet forsøger den ikke på forhånd at afmærke tydelige grænser mellem 'dem' og 'os', polakker og jøder, eller 'onde' polakker (som passivt eller aktivt støttede partiets beslutning om jødernes udryddelse ${ }^{\mathrm{io}}$ ) og 'gode' polakker. På samme måde prøver Dammas - som på én gang er instruktøren, fortælleren og hovedpersonen i filmen - ikke at markere nogle faste grænser i forhold til sin polsk-jødisk-danske oprindelse. Når grænsen bliver markeret, sker det i processen af interaktion mellem ham og stedet, samt de mennesker han taler med.

Ideen til filmen er enkel: Den cirka trediveårige instruktør ankommer til den sydvestlige polske by Wrocław (på tysk Breslau) med håbet om at finde den gamle tyske skænk, som hans familie har ejet i en række år. Han når til huset, hvor hans familie boede, inden de skulle rejse ud af Polen, og på vaklende polsk spørger han

7 Bl.a. med Grand Prix 2008 til den internationale film festival OFF Cinema i Poznań og med Bronze Warsaw Phoenix til the Jewish Motifs International Film Festival i 2007.

8 Jeg har udførligt skrevet om filmen et andet sted, på polsk (Mrozewicz).

9 Marcel Łoziński: Siedmiu Żydów z mojej klasy (1992), Maria Zmarz-Koczanowicz: Dworzec Gdański (2005), Ewa Szprynger: Rachela na Dworcu Gdańskim (2006).

Io Denne anklage er tydelig både i de nævnte polske dokumentarfilm om marts 1968 og hos Kofler. 
de gamle beboere, om de kan huske skænken og ved, hvor den kunne være nu. Dammas vil gerne købe den. Undervejs i samtalerne med de ældre mennesker bliver skænken mindre vigtig, og andre emner kommer automatisk i fokus: Dammas' samtalepartnere kommer af sig selv ind på historie, politik, familie og religion. ${ }^{\text {II }}$

Kredens starter med en prolog, der kondenserer filmens hovedproblemstilling. I første optagelse vises en hånd, der på et stykke papir tegner konturerne af en skænk. Fortælleren siger off screen på dansk:

"Min onkel har tit fortalt mig en legende om, hvordan han fik engageret fire stærke mænd fra den lokale bar for en flaske vodka til at flytte familiens skænk. Fire mænd bar en I5o kilo tung, tysk fabrikeret skænk fra den ene side af vejen til den anden en dag i slutningen af november 1969, da min familie flygtede fra Polen til Danmark.”

Herefter bliver der klippet til et sort-hvidt fotografi af den daværende partileder, manden bag udrensningerne, Władysław Gomułka. Nu lyder hans stemme (voiceover): "Jeg regner med, at denne kategori af jøder snart vil forlade vores land", 12 og derefter hører vi klappende hænder, ${ }^{13}$ mens en skriftlig note informerer om, at cirka tyve tusind polske statsborgere med jødisk oprindelse måtte emigrere fra Polen efter marts I968. Efterfølgende vises sort-hvide billeder fra forskellige glædelige familiebegivenheder i Wrocław, dvs. fra perioden inden emigrationen. Dammas fortsætter:

”Jeg har altid ønsket at vide mere om mine forældres fortid i Polen. Men det går altid galt, når vi taler om det. Jeg får altid at vide, at det kapitel er afsluttet i vores familiehistorie. Om jeg spørger min farmor i Israel ...” (her farmor i halvnær beskæring) ”... eller min egen mor i Danmark...” (morens ansigt i lignende beskæring) "... der er nogle døre i ens liv, man er nødt til at lukke, og de skal helst forblive lukkede. Så jeg holdt op med at spørge.”

Prologen udtrykker en række spændinger, som ligger til grund for både indholdet, æstetikken og metoden i filmen. Grundaksen er et dialektisk samspil mellem 'legende' og 'historie', som på æstetikkens niveau udspiller sig mellem det dokumentariske og det quasi-fiktive. Tegningen og fortællingen om fire stærke mænd hører til legende-polen, mens fotografier, Gomułkas stemme og ovation (på lydsiden) befinder sig ved den modsatte pol, historiens. Samtidig er der to

II Jeg har kaldt filmen for et socialt eksperiment, fordi hele arrangementet var spontant. Hverken Dammas eller hans kameramand Marcin Sauter vidste og kunne forudse, hvordan filmen ville udvikle sig - husets beboere blev ikke informeret på forhånd om interviews, ligesom Dammas ikke vidste, om skænken ville blive fundet. Med andre ord var filmens konklusion ikke udpeget på forhånd. Kamera var ikke skjult, men diskret (Mrozewicz I62).

I2 Sætningen stammer fra Gomułkas tale holdt den I9. marts I968 (Osęka).

I3 Kun i den registrerede ovation (dvs. den faktiske reaktion på Gomułkas tale) kan man i filmen høre en subtil anklage af (nogle) dele af det polske samfund, der tillod fordrivelsen af polakker med jødisk oprindelse. 
dimensioner af historie på spil: den officielle (Gomułka, hans registrerede stemme, ovation) og den private (fotografier fra familiealbum). De to poler - legende og historie(r) - er flettet sammen ved hjælp af en hukommelse, som fortælleren kun har indirekte adgang til via legenden, familiealbummet og generationerne. Moren og bedstemoren repræsenterer to forskellige generationer og udgør referencen til en kontinuitet i jødernes (fordrivelses)historie. ${ }^{44}$ Fra prologen kan vi også slutte, at 'spørgsmålet om skænken' (stillet til husets beboere) har en særlig funktion i filmen - det erstatter det spørgsmål, som Dammas aldrig kunne få svar på fra sine tavse familiemedlemmer, nemlig spørgsmålet om fortiden (Mrozewicz I6I). De to dimensioner, det dokumentariske og det quasi-fiktive, supplerer kreativt og forholder sig kritisk til hinanden, og på den måde problematiserer de både hukommelsen som forvrænget og muligheden for at rekonstruere fortid i en dokumentarfilm. Indføring af de quasi-fiktive elementer er desuden en metode til at indføre en fortalling, hvor den manglede.

Et eksempel på, hvordan Dammas' subjektive oplevelse af fortiden overføres på det æstetiske plan, er en kort scene efter telefonsamtalen med moren, som slutter med hendes ord: "Det er et lukket kapitel". Herefter klippes der fra farve- til et sort-hvidt, næsten fotografisk skud af familiens gamle hus ude fra gaden. Efter et længere øjeblik åbner Jacob vinduet inde fra lejligheden. Ind i det 'fastfrosne' billede indføres derved bevægelse og, efter at instruktørens fulde silhuet bliver synlig, vender farverne tilbage. På den kondenserede og rent filmiske måde vises, at fortiden kun kan betragtes med nutidige og personlige briller på. Kun på den måde er det muligt at trænge indenfor. Dernæst klippes der til optagelser af lejlighedens rum og detaljer. Der udtrykkes derved en forbindelse mellem sted og posthukommelse. Via fantasi og kunst er det muligt at åbne "det lukkede kapitel", den 'frosne' kronotop. Stedet og skænken - rester, fragmenter af den tabte tid, får i Dammas' fremstilling en aura, netop fordi de kun er rester. Som et fotografi giver de en illusion af forbindelsen med (familie)fortiden. ${ }^{\mathrm{I}}$

Denne næsten naive tilgang, der kendetegner Dammas' oplevelse af stedet, er et udtryk for hans - og anden generations - særlige bevidsthedsform. Den peger på, at der ikke findes et genkendeligt mønster, som Dammas kan forholde sig til, fordi den polske virkelighed ikke eksisterer i hans hukommelse, og hans viden ikke er stor nok til at stille spørgsmål. I artiklen "Remembering the Holocaust: Mourning and Melancholia” diskuterer Frank Ankersmit det meget omtalte ${ }^{16}$ problem om repræsentation og æstetik i forhold til Holocaust (Ankersmit I63-I67). Ankersmit

I4 Det er ikke kun marts I968, der henvises til i filmen. Mange polakker med jødisk oprindelse var i I968 bange for, at urolighederne ville udvikle sig til et andet 'Holocaust'.

I5 Den slags auratisk erfaring af et oprindelsessted er skildret af Salman Rushdie (som her beskriver sin egen hukommelse): "Hukommelsens brudstykker blev tillagt en højere status [...] netop fordi de var rester; fragmenteringen medførte, at trivielle ting var som symboler, og det verdslige fik en hellig betydning. Her er der en klar parallel til arkæologi. De smadrede antikke krukker [...] er spændende at opdage, selv hvis de kun er fragmenter af de mest dagligdags objekter" (Rushdie I2).

I6 Siden Adornos berømte essay (Adorno 7-3I). 
skelner mellem to mulige måder at forholde sig til Holocaust på: den historiske diskurs og hukommelsens diskurs. Mens historiens diskurs stræber efter objektivisme og intellektuel bemægtigelse af emnet, kendetegnes hukommelsens diskurs af en bevidsthed om, at det ikke er muligt at komme i besiddelse af tingenes kerne. Derfor foretrækker den alene at pege på det uudtrykkelige, at efterlade et 'tomt sted', som man kan omfavne, men ikke erobre.

Skænken, eller - den manglende skank, synes at være sådant et tomt sted. Den er en genstand, der kondenserer fortiden, den er den tabte tids pars pro toto. Gennem den undgår Dammas at forholde sig direkte til fortiden. I stedet for at spørge lytter Dammas, og på den måde skabes der et hér og nu, som optages på kamera. Nutiden og den direkte erfaring dominerer over en strukturering af en allerede eksisterende viden og følelser, ${ }^{17}$ som ifølge Ankersmit kendetegner den historiske diskurs (og i høj grad den første generations diskurs). Dammas giver derved udtryk for den manglende viden og manglende erindring, som han forsøger at kompensere for via forskellige formidlinger, hvilket er typisk for posthukommelse.

Scener optaget i huset er flettet sammen med telefonopkald til moren i København. Det er kun på den måde, via telefonforbindelsen (med moren) og det danske sprog eller dansk accent, at Danmark, Jacobs fødested, er til stede i filmen. Morens stemme, formidlet af telefonrøret, konnoterer både Dammas' forbindelse og afstand til sit 'hjemland'. Men også morens Wrocław forbliver på afstand. I sidste scene inden epilogen ser vi instruktøren sidde $u d e$ på trappeopgangen, efter hans utallige forsøg på at komme ind i den lejlighed, hvor skænken formodentlig fandtes. Trappeopgangen kan opfattes som en tærskel- eller mellemzone, som definerer Dammas' position både i forhold til den historie, der "skjuler" sig bag dørene, og i forhold til morens hjemland. Det er dog netop i denne scene, at Dammas beslutter sig til ikke at vende tilbage til Danmark. Mødet med stedet har gjort noget ved ham, lige som hans kreative handling (filmen) gør noget ved stedet. Han beslutter sig for en slags dobbelt eksil - eller statsløshed, måske for at gentage morens skæbne - væk fra (diasporaen i) Danmark og ind i sit fremmede hjemland, hvor han "kunne være blevet født", som en af de gamle beboere siger, og hvor han befinder sig i en 'tredje position', som trappeopgangen er metafor for - både inde i bygningen og uden for lejligheden.

Den tunge tone i filmens sidste scene bliver balanceret af epilogen, som genoptager legen med forskellige grænser i filmen og indfører humor og distance. Det er blandt andet de træk - fantasi, distance og åbenhed over for en leg, der kendetegner en postdiasporic tilgang i modsætning til en postexilic.

I7 Den type direkte erfaring kendetegner ifølge Ankersmit børnenes mindesmærke (Children’s memorial) i Yad Vashem (Jerusalem) i modsætning til andre mindesmærker, som findes der. 


\section{Statsløs og placeret igen: faren og sønnen i Jacob Koflers Stats/øs}

Hjemlandets dystre billede finder vi også i Jacob Koflers Statsløs (2004), dog her på en helt anden måde. Statsløs lægger vægt på de polske jøders forfølgelseshistorie og det autokratiske systems altomfattende mekanisme, som gennemtrænger ikke kun myndighedsapparatet, men også store dele af samfundet og afføder social kontrol blandt medborgere. Den polske virkelighed fra slutningen af tresserne er skildret som overordnet dystopisk. Filmen starter med en kamerabevægelse, som følger et sæt jernbanespor. Billedet peger både på jødernes ufrivillige vandring og evige liv i diaspora, ${ }^{\mathrm{I} 8}$ og henviser også - som en topos - til Holocaust og kz-lejre. Samtidig kan man læse billedet som en bevægelse ind $\mathrm{i}$ en erindring og fortid, som ikke nødvendigvis er behagelig og ønsket. ${ }^{19}$

Statsløs handler tilsyneladende om samme emne som Kredens, men den kan kun til en vis grad siges at være lavet ud fra posthukommelse. Hvor Dammas lægger vægt på sin egen oplevelse af morens fortid, så er Koflers film koncentreret om farens erindringer og beretning om fortiden. Koflers film er, i modsætning til Dammas' eksperimentelle og interaktive fremgangsmåde, i høj grad planlagt og struktureret i forvejen. Måske er det, fordi Kofler blev opdraget af sin far til at være "et hundrede procent dansker og endnu mere", som faren udtrykker det ved filmens slutning, og hvad angår nationalitet, har han ikke en sammensat - 'suspenderet' eller hybrid - identitet. Kofler taler ikke polsk, og hans udgangspunkt er klart indlejret i det danske sprog og samfund. Mens Dammas' perspektiv er transnationalt, foregår Koflers internationale tilgang "mellem velafgrænsede nationale størrelser i forskellige kombinationer" (Larsen, Tekster 32).

Disse forhold er afspejlet i filmens endelige form, som benytter tv-dokumentarens æstetik: Den er velstruktureret, fremlægger begivenheder på en informativ, forståelig, kronologisk måde, rigeligt illustreret med billeder og film fra arkiver (f.eks. af uroligheder på Warszawas gader d. 8. marts 1968). Selve fortællingen er både på det verbale og visuelle niveau flydende, med jævnt tempo og en klar, logisk struktur, en tydelig begyndelse og afslutning, uden nogen markante selvrefleksive, æstetiske eller andre brud. Koflers nysgerrighed omkring sin fars fortid og trangen til at fortælle om den er et udtryk for hans posthukommelse (han siger bl.a.: "min far har aldrig talt om sin fortid i Polen, selvom jeg havde bedt ham om det" [sic]), men selve måden at realisere filmen på er ikke dens bearbejdning. Snarere burde man tale om fortællingens to niveauer: Farens eksilfortælling er indlejret i

I8 Kofler fortæller i voice-over: "I I969 ankommer et tog til Københavns hovedbanegård. De rejsende er jøder på flugt fra nye forfølgelser i det kommunistiske Polen. De næste mange måneder ankommer i alt 3000 jøder til Danmark. En af dem er min far”. Samme optagelser bruges senere igen, når faren fortæller om flugten med kun to kufferter og uden at vide, hvor man skulle flygte hen.

I9 Jernbane-topos finder vi i alle tre værker - både hos Dammas (i begyndelsen af filmen vises han i tog på vej til Wrocław) og i flere variationer hos Swiderska. 
den overordnede ramme skabt af sønnen, der påtager sig rollen som et vidne og 'medie' for farens historie.

Selvom filmen bruger velkendte fortællestrategier, har den dog flere træk af accented cinema, herunder selve emnet, flersprogligheden, især farens dansk med polsk accent, nostalgisk tone mv. Men til trods for det personlige tema kan stilen i filmen ikke betegnes som 'subjektiv'. Koflers forståelse af dokumentarismen er tydeligt præget af journalistikken, hvilket især kommer til udtryk i måden at gennemføre interviews på, i en sandheds-orienteret undersøgelse og i en tydelig strategi for at knytte det konkrete menneske og historien sammen. ${ }^{20}$

Filmens midler tjener det overordnede mål at belyse sandheden på den mest troværdige og objektiviserende måde. For at belyse begivenhederne fra flere synspunkter interviewer Kofler: I) et familiemedlem: sin morfar, 2) en ekspert: en polsk forsker på en journalistskole og 3) en ansvarlig for udryddelser: Kazimierz Kąkol. I filmens anden del, der foregår i Danmark, interviewes Isi Foighel, daværende formand for dansk flygtningehjælp og senere minister i Poul Schlüters regering. Benyttelse af arkivbilleder er et retorisk greb, der gennem sammenligning skal forstærke fortællingens autenticitet. Koflers strategi er at øge filmens historiske dimension. Statsløs har også en klar konklusion: Fordi den gruppe polske jøder, der kom til Danmark dengang, er en af de bedst integrerede indvandrergrupper i det danske samfund - som vi får at vide fra Foighel - så er det værd at være åben over for og hjælpe indvandrere. Man får som modydelse taknemmelighed og godt samarbejde.

Kofler stræber med andre ord efter en rekonstruktion af begivenhederne - han lader ikke det 'tomme sted' forblive tomt. Alligevel støder han på nogle benspænd, der ikke lader ham komme helt frem til det, der 'virkelig' fandt sted i I968. Det sker bl.a., når han interviewer Kazimierz Kąkol, redaktør på bladet Prawo i życie /"Lov og liv”/, som i høj grad var ansvarlig for den antisemitiske kampagne. Kąkol giver ingen forklaringer og nægter ligefrem, at der overhovedet fandt en antisemitisk kampagne sted. Da Kąkol finder ud af, hvad der er det virkelige emne for interviewet, nægter han at tale engelsk, som det ellers var aftalt i forvejen. Forløbet udvikler sig her fra det planlagte til det performative.

Som Ankersmit påpeger, er anden generations oplevelse af traumatiske begivenheder forankret i nutiden, mens strukturering af de allerede eksisterende følelser og viden dominerer hos dem, der direkte har erfaret begivenhederne. I Statsløs er det sidstnævnte perspektiv, der, via farens viden og hukommelse, strukturerer filmen. Men Kofler har et mønster at forholde sig til, som han benytter - det åbne samfund, dvs. den vestlige, demokratiske samfundsmodel, hvor ytringsfrihed er idealet, og hvor man bl.a. ikke behøver at "lære" at læse pressen "mellem linjerne”, som den interviewede forsker siger i filmen. Måske derfor lyder nogle af Koflers spørgsmål lidt

20 Om tendenser i dansk tv-dokumentarisme efter 2000 se Bondebjerg 2008. Her især sider 453-457 om DR2s satsning på "den unikke, kunstneriske og journalistiske dokumentar" (Bondebjerg 453) og kanalens tendens til at forbinde den filmiske dokumentar og tv-dokumentaren. 
naive - hans 'mønster' passer ikke til det, han forholder sig til - og på den måde afspejles samme 'naivitet', som Dammas giver udtryk for. Målet med denne strategi kunne også læses som tilpasning af spørgsmålene til filmmodtagernes viden om den polske virkelighed fra slutningen af tresserne og det kommunistiske regime. Om danskernes uvidenhed om kommunismen og Østeuropa fortæller faren ved slutningen af filmen. Danmark "var et dejligt land, [...] men utroligt uvidende om situationen i Østeuropa, om kommunismens galopperende fremgang. Det var studenteroprørs tid..." Faren fortæller, hvor chokeret han var, da han i forbindelse med en fest på et kollegieværelse så plakater med Lenin, Marx og Che Guevarra på væggene. ”Tænk, at man betragtede dengang [sic] de mennesker på portrætterne som popidoler [...] Det var den tid, hvor DKP og venstresocialismen blomstrede. Tænk at satse på de mennesker på portrætterne, dem som forårsagede mange lidelser for andre folk... De forstod ingenting.”

Og hvad er det for et Polen, der vises i Statsløs? Hjemlandet er her uadskilleligt fra det billede af Danmark, der opstår i filmens løb. Følelsen af fremmedhed over for Polen er dominerende i farens fortælling. Den bygger tydeligt på en binær relation mellem eksklusion og indlejring, som Naficy påpeger som et af de vigtigste træk ved accented exilic cinema. Hjemlandet inkarnerer fortiden, mens gæstelandet repræsenterer nutiden og fremtiden. Farens fortælling bygger samtidig på en strategi, som Svend Erik Larsen kalder for 'udelukkelsesstrategi'. ${ }^{21}$ De to lande udelukker hinanden og, i modsætning til mange eksilfortællinger, er det hjemlandet, der ses bort fra. Mens Danmark fremstår som et åbent og trygt samfund (selvom det også er lidt naivt), er fortidens Polen dystopisk, grusomt og lukket. Når en optagelse fra det polske arkiv vises, lyder farens voice-over neddæmpet, som om han er bange for at blive aflyttet: "Det var ikke et åbent samfund, som du kender det. Alle kunne være dine fjender. Ingen vidste, hvem der observerede, aflyttede eller udspionerede dig”. ${ }^{22}$ Mens faren fortæller om sin og andre jøders voksende frygt og henviser til Holocaust, vises der et arkivbillede med teksten "Arbeit macht Frei” over indgangen til en af kz-lejrene. Følelser som tristhed, ensomhed og fremmedgørelse dominerer i fortællingen om Polen.

Det er altså en polariseret relation, der fremtræder i Koflers fars beretning, hvor det danske samfund fremstår som den åbne kronotop med muligheder for fremtiden. Faren har sørget for, at hans søn ikke skulle kæmpe sig igennem sit liv med en hybrid eller splittet identitet - han tog en meget bevidst beslutning om ikke at lære ham polsk. Det var med andre ord en beslutning om at indlejre sin søn i et nyt land. Og for at kunne leve på det nye sted skal man, ifølge faren, udelukke både det andet land og fortiden (jf. farens mangeårige tavshed). Ved filmens slutning kan vi for første gang se gamle billeder i farve: faren sammen med den lille, hvor de begge to smiler i en varm og kærlig stemning.

Både faren og Jacob Kofler bevæger sig altså "væk fra diasporaen som skæbne" - i retning mod 'centrum' og en fast, stabil identitet knyttet til stedet, som dette centrum

2I I modsætning til 'integrationsstrategi' (Larsen, “Lad os genskabe”).

22 Den neddæmpede stemme i fortællinger om Holocaust hos familier, der har erfaret den, siges ofte at være et træk, der nedarves gennem flere generationer. 
giver plads for.

\section{Breaking the frame - The Border Breaking Bunch}

"Litteraturens mødesteder konfronterer konkrete erfaringer med erfaringsmønstre der ikke har plads til de nye erfaringer” (Larsen, Tekster 57). I Maja Magdalena Swiderskas roman - denne genreangivelse står på titelbladet konfronteres 'grænse-krydsnings-erfaring' med lukkede og 'afgrænsende' erfaringsmønstre. Bogens ironiske og tomt lydende motto er et uddrag fra FN's Verdenserklæring om Menneskerettighederne fra I948: “I. Enhver har ret til en nationalitet. 2. Ingen må vilkårligt berøves sin nationalitet eller nægtes ret til at skifte nationalitet" [oversættelse: http://www.ohchr.org/EN/UDHR/ Documents/UDHR_Translations/dns.pdf, 7. april, 20I4, red.]. De polske jøders berøvelse af deres statsborgerskab i 1968 er Swiderskas udgangspunkt for overvejelser om nationalitetens og den "påtvungne" identitets indflydelse på forskellige menneskelige skæbner. Skæbnerne omfatter både dem, der ikke var beskyttet af FN-konventionen - hovedpersonen M.s bedsteforældre, og dem, der teoretisk set burde have været det - hendes forældre. I høj grad handler det også om M.s egen, ikke selvvalgte danske nationalitet, samt nutidens Danmark og danskere, som er genstand for kritik i bogen. Men det er ikke en simpel kritik. Louise Zeuthen påpeger ud fra et performativitetsteoretisk synspunkt, at: "en kritik formuleret inden for rammerne af traditionelle genrer på grundlag af uproblematiseret repræsentation er en selvmodsigelse” (Zeuthen II3). Hos Swiderska iscenesættes et kreativt, selvrefleksivt, kritikaffødende sammenstød mellem den polske og den danske kronotop, på både det tematiske og det diskursive niveau, hvor det sidstnævnte også kan betegnes som repræsentationskritisk. ${ }^{23}$

Bogens tema er en familiehistorie fortalt i et samtidsperspektiv, hvor de to foregående generationer har erfaret en konstant påtvunget grænsekrydsning. Bedstemoren flygtede flere gange under 2. Verdenskrig; M.s far blev efter marts I968 tvunget til at forlade Polen, hvorved også M.s mor forlod hjemlandet og rejste til Danmark. Denne erfaring - grænsekrydsningen - er nedarvet til M., født i Danmark i 1976 (præcis som forfatteren). Den påvirker hendes virkelighedsopfattelse, handlinger og relationer til andre, og den skaber en mellemposition, hvorfra de to lande (kronotoper) betragtes med distance og $i$ forhold til hinanden. Denne mellemposition afspejles af det transitive rum i bogen - flyrejsen fra København til Warszawa, som er rammen om de fleste (post)erindringer, der starter i I945 og slutter i I989. I de første fire kapitler er M. "minus ... år", hvilket peger på en (gen)fortælling af familiehistorie ud

23 Zeuthen understreger, at "kunstens politiske budskaber ikke længere findes på værkets tematiske niveau" (Zeuthen II5). Jeg ser det ikke som en selvmodsigelse, når et værk har et politisk eller kritisk budskab på både det tematiske og diskursive niveau. 
fra M.s posthukommelse (støttet af grundig research, bl.a. på Instituttet for National Erindring i Polen).

Det transitive rum, som fortælleren/M. befinder sig i, kan i sig selv opfattes som en symbolsk modstandsposition mod det snævert forståede nationalitetsbegreb og som et spørgsmålstegn ved FN-konventionen (bogens epigram) og dens berettigelse i forhold til de mennesker, der på grund af forskellige omstændigheder befinder sig 'i mellemrummet', dvs. er statsløse og/eller flygtninge. Som Hannah Arendt bittert og ironisk udtrykte det i sit desillusionerede essay "We Refugees" fra I943: "Hvis vi skulle begynde at fortælle sandheden om, at vi ikke er andet end jøder, så ville det betyde, at vi ville udsætte os for den skæbne, som mennesker lider, der, ubeskyttet af en særlig lov eller politisk konvention, ikke er andet end mennesker" (Arendt II8, oversættelse AEM og red.). Giorgio Agamben kommenterede dette udsagn på følgende måde: "I det nationalstatslige system viser de såkaldte hellige og umistelige menneskerettigheder sig at være fuldstændig ubeskyttede i det øjeblik de ikke kan karakteriseres som statsborgerlige rettigheder. [...] [F] lygtningestatus opfattes altid som en midlertidig tilstand, som enten skal ende med opnåelse af statsborgerskab eller hjemsendelse. En permanent status for mennesket som sådant er utænkelig inden for nationalstatens love" (Agamben I5-28, oversættelse AEM og red.). Swiderska giver udtryk for en permanent, både nedarvet og selvvalgt, flygtningetilstand, en 'suspenderet' identitet.

Alt dette er nuanceret på bogens diskursive niveau. Bogen er præget af performative strategier, selvrefleksivitet og afvigelser fra genre- og mediemæssige konventioner. ${ }^{24}$ Dertil kommer den konstante overskridelse af grænsen mellem fiktion og forfatterens privatperson, som gør det svært for læseren at afgøre, hvor det 'iscenesatte' slutter, og det 'virkelige' starter. Swiderska beskriver ikke - hun performer sin posthukommelse og det blik på virkeligheden, den giver. The Border Breaking Bunch kendetegnes af det, som Zeuthen nævner blandt den performative kunsts og litteraturs mest påfaldende træk: Den udstiller sin egen repræsentation som repræsentation og har et kritisk potentiale, der er subtilt og flertydigt og aktiveres i relationen til modtageren (Zeuthen II4).

Hovedpersonen M.s hybride identitet er en ramme for en ambivalens, der skabes omkring forskellige opfattelser af nationalitet og identitet, som belyses fra to hovedperspektiver: det 'grænsekrydsnings-erfarne', inkluderende (det jødiskdanske) og det essentialistiske, ekskluderende (det danske). Swiderska skaber en konfliktuel konstellation, som stræber efter at problematisere enkle fortolkninger af begreber som frihed, ytringsfrihed, grænse, nation, sted mm. Personen Mama Es, for

24 Lars Bukdahl udtrykker det således: "Mange ting, man ikke må, når man skriver romaner i Danmark, gør Maja Swiderska på én gang [...] Hun skriver en roman af lutter begyndelser og digressioner; hun inkluderer [...] en lang række [...] meta- og selvrefleksioner [...] hun nægter sig noget der ligner et plot ud over en bunke familieanekdoter og en flyrejse, der har virkelig svært ved at komme ud af stedet; hun skriver på dansk og engelsk og polsk; hun udstiller en række kornede s/h-fotos; hun benytter sig af talrige konkretistiske typo-effekter, tomme kasser og cirkel-opsætning [...] hun opererer med indtil flere fortællere eller rettere fortællerudspaltninger, M., Lady M.I.G, Sister C, delvist (!) Mama Es og Mr. Möi” (Bukdahl). 
eksempel, der kom til Danmark "ved en misforståelse" (I5), kan kun trives i transitive rum. Mr. Möi, indlejret i teksten som en modfigur, opfatter til gengæld grænsen som nødvendig for at sikre stammens og stedets homogenitet:

"Mr. Möi den Monokulturelle har forklaret Mama Es, at når nu man er en del af en lille bitte stamme, så er det bedst at falde til og ikke skille sig ud. Homogenitet er målet. Ensartethed, middelmådighed. [...] Mama Es har fået hjernerystelse. Hun har netop skudt hovedet gennem loftet. Det svirrer. Der er også alt for lavt.” (5I)

Citatet henviser til den opfattelse, som bl.a. James Mellon udtrykte, at "danskerne [ikke er] en nation [...] de er en stamme... En stamme har en indre styrke, er homogen i en grad en nation aldrig kan nå... Deres sammenhæng som folk skyldes [...] en fremhæven af ensartetheden. Her gælder ikke 'både/og', men 'hverken/eller”' (Mellon 7). Mr. Möi repræsenterer en "reaktionær stedsopfattelse", der bygger på en "tæt forbindelse mellem sted og en entydig form for identitet [...] et ønske om at vise hvordan sted har autentiske rødder i historien [...] et behov for en klar fornemmelse for grænser omkring stedet" (Ringgaard 92; Cresswell 72).

Via Mr. Möi-figuren bliver forskellige træk ved den danske velfærdsmodel (som aldrig eksplicit bliver nævnt i bogen), som egalitarisme, individernes solidaritet med/afhængighed af staten og magtens centralisering, fremstillet som en udelukkelsesstrategi over for alt, der ikke passer ind i modellen, som en usynlig, næsten diktatorisk magt. Den nuværende danske kronotop bliver sammenlignet med den polske kronotop og dens fortidige totale statskontrol. Kritikken af velfærdsstaten som umyndiggørende individet, som et ansigtsløst, anmassende system, genkendes. Swiderska knytter også an til den kritik af den danske velfærdsstat, der hedder "hyggeligt, men lavt til loftet" (Harnow Klausen 177, I79), og af den middelmådighed ("at passe til masse", som det hedder hos hende), som bl.a. Axel Sandemose udtrykte med Janteloven i En flyktning krysser sit spor (I933).

Hvor Mr. Möi står for et lukket erfaringsmønster, når protagonisten M., takket være sin position i det 'tredje', transitive rum (posthukommelsens og distancens rum), at kaste kritisk lys på lukketheden og åbne for de fastfrosne forestillinger om 'Østblokken’ og konkret Polen. Et eksempel er M.s refleksioner over Warszawa, familiens oprindelsessted:

"Byen er blevet beskrevet så mange gange, at det er blevet en kliché [...] Den er trist, ja, og fattig, ja, men på vej frem, ja, og grå, mmmm ja. Faktisk er det selve byen, dens fysiske rum, dens gråhed, M. kan længes efter. Selvom Warszawa er det mest tilosede og klistrende sted, M. kender, er det samtidig det mest rensende. En æstetisk renselse. En sansemæssig renselse. [...] Det er frigørende. Immaterielt. [...] Engang efter et ophold var hun vendt hjem til sin lejlighed og havde malet alt gråt i gråt. [...] Det holdt ikke to måneder. [...] Måske fordi det var i København og ikke et andet sted. Måske fordi det regnede særlig meget den vinter. [...] Ligesom i detektivromaner eller thrillere. Hvor opklaringen skal søges i det grå mørke.” (53) 
Swiderskas strategi er at etablere den stereotype forestilling om Warszawa som en intertekst i M.s personlige oplevelse af byen. Selve stereotypen benægtes ikke, men den bliver åbnet, sat i bevægelse. Warszawas "gråhed" transformeres til en kvalitet, der er frigørende, "rensende" og noget, som M. savner hjemme i København. Med Larsens ord kunne Swiderskas strategi betegnes som en 'integrationsstrategi', hvor der i fortællingen er plads til 'både/og': Byen er både klistrende og rensende. I udsnittet blandes den fænomenologiske oplevelse af byrummet med de kulturelle (en kliché, detektivroman, thriller) og symbolske (frigørende, immaterielt) betydninger. Samtidig er stedet ikke lukket og afgrænset - Warszawa og København indeholder en resonans af hinanden. Sammenligningen med detektivromaner og thrillere henviser til de udbredte noir-klichéer i forestillinger om de østeuropæiske lande i Vesten. Men for M. er det netop i denne floskel, "opklaringen skal søges”.

Ved siden af de nævnte kronotoper (den polske og den danske) findes der også en helt særlig kronotop, som kendetegnes ved mangel på sted - det jødiske ikkested, der er spredt ud i hele bogen som fragmenter af historier og associationer, der latent ligger under fortællingens overflade. Med den intertekstuelle strategi igangsætter den stedsløse kronotop de velkendte forestillinger og fortællinger fra Holocaust-beretninger. De flettes sammen med M.s familiehistorie og hendes eget liv som minder og genkommende (små) traumer. Et eksempel er en henvisning til en sko-topos, som alle med viden om kz-lejre vil genkende:

"Der er [...] masser af sko at vælge imellem. Før afrejsen skal de alle afprøves foran spejlet. [...] De er taget ud af kasserne og ligger nu i en vældig bunke midt i stuen. Sko i bunker, bunker af sko. (Store sko, små. Kvindesko, herresko, små sko, for små sko, pæne sko, slidte). Sko er vigtige [...] med gode sko kan man muligvis nå at flygte.” (45, fremhævning AEM)

Henvisninger til kendte fortællinger, historiske bøger, ${ }^{25}$ avisartikler m.m. kan betegnes som en 'svingdørsstrategi', hvis mål er at markere bogens autobiografiske dimension. Men gennem de performative, medie- og genreoverskridende strategier skabes der også en distance til den 'virkelige' virkelighed. Det gælder billeder indlejret i bogen, som indgår i relation til tekstens indhold, og som ved første øjekast skaber den dokumentariske reference og er forfatterens 'spor'. De er alle sort-hvide og ikke særlig velkomponerede, og på et af billederne kan vi endda se en finger (forfatterens?). Men kigger man nærmere efter, bliver deres 'dokumentariske' udtryk tvetydigt. Et eksempel er en gruppe billeder, relateret til Aleja Przyjaciół (Vennernes Allé i Warszawa), hvor flere af bogens handlinger og erindringer finder sted. Det første billede forestiller et gadeskilt “Aleja Przyjaciół” hængende på et hus (I4), det andet

25 Et eksempel er en i Polen heftigt omdiskuteret bog af Jan T. Gross Sąsiedzi (Naboer), som handler om en massakre i landsbyen Jedwabne, hvor de jødiske beboere blev brændt i en stald i juli I94I af polakker (og ikke, som påstået $\mathrm{i}$ en lang årrække i officiel polsk historieskrivning, af tyskere). Den debat er der tydelige henvisninger til i bogen, hvor protagonisten M. arbejder på "sit projekt om naboer" (I3). 
forestiller samme billede, men indrammet og hængende i en lejlighed, antageligt M.s/ forfatterens (28), mens det sidste er et billede af selve skiltet hængende på væggen i lejligheden (I55). Derudover findes der et gammelt billede af selve gaden (56). Der opstår derved en relation mellem billeder og historien - en åbning mod 'virkeligheden'. Men der findes også en intertekstuel relation mellem selve billederne, som paradoksalt skaber afstand til den 'rene virkelighed' og synes at pege på, at det er umuligt at adskille det virkelige sted fra dets repræsentationer - billeder, skilte, skiltets billeder og (underforstået) selve fortællingen. Stedet bliver sat ind i erindringens og fortidens ramme (inkarneret af fotografi), men også placeret i et netværk af mellemtekstuelle referencer, som ophæver den direkte relation til fortiden. Swiderska skaber en illusion om det dokumentariske og leger med selve det at etablere og overskride grænsen mellem det iscenesatte og 'det virkelige'. Den åbenbare 'svingdørsstrategi' synes at være benyttet ikke for at opnå virkeligheds-effekten (eller -affekten), men for at markere posthukommelsens komplekse, formidlede og kreative (performative) relation til fortiden og de steder, den er forbundet med.

Swiderskas overordnede strategi er med andre ord en konstant nedbrydning, ofte med en humoristisk undertone, af de netop etablerede rammer, hvilket skaber en oplevelse af diskontinuitet og en stædig forskydning af meninger. En form for kritisk diskontinuitet er ifølge Hirsch et kendetegn ved anden og følgende generations fortællinger og en uomgængelig strategi i formidlingen af en erfaring af traumet (Hirsch 29-3I).

Selvom Swiderskas litterære mødested nuancerer de forskellige kronotoper i forhold til hinanden, så fremtræder der i bogens løb et billede, hvor den danske kronotop er overordnet dystopisk, mens den polske fremstår nostalgisk. Lige som traumerne skal denne optik opfattes som nedarvet fra forældrene. Selvom Swiderska bryder med en radikal polarisering typisk for eksilfortællinger, kan man spore denne eksiloptik i bogen. Men netop den drilske benyttelse af de performative strategier og ikke mindst 'svingdørsstrategi' undergraver den vertikale, binære relation mellem fortiden og nutiden. Referencer til 'det virkelige', som nemt kunne tages for givet, viser sig i The Border Breaking Bunch involveret i en leg med forskellige grader af formidlinger, som posthukommelsen sætter i gang.

\section{Posthukommelse og cestetik}

Sociologen Ron Eyerman skriver om anden generations bearbejdning af fortiden: "distancen fra begivenheden [...] [gør at] hver kommende generation genfortolker og repræsenterer den kollektive hukommelse om begivenheden i forhold til egne behov og muligheder" (Eyerman I5). I denne artikel har jeg argumenteret for, at repræsentationer af det 'andet' sted og den 'anden' tid er præget af et dynamisk forhold mellem både de foregående generationers fortiede traumer $o g$ kunstnernes identitet og forankring $i$ deres 'eget' sted. Formålet med artiklen har været at vise, at posthukommelse kan benyttes som en forståelses- og analyseramme for en del af anden generations kunstneriske bearbejdninger af familiefortid. Overordnet kan de omtalte værker henregnes til selv- 
biografiske genrer inden for litteratur og dokumentarfilm (og ikke til bekendelses- eller erindringsgenrer), men posthukommelsesrammen indebærer en række afgrænsninger: Den peger på et kulturelt traume som (gen)fortællingens baggrund; den er præget af generationsdistancen som det formidlende samtidsfilter og ikke mindst det æstetiske filter, der tillader en kreativ bearbejdning af fortiden; sidst, men ikke mindst, indebærer den en refleksion over det i bund og grund etiske spørgsmål om repræsentation, dvs. hvordan kunsten kan forholde sig til en traumatisk begivenhed, som i de omtalte værker omfatter jødeforfølgelser, herunder Holocaust.

Posthukommelse udgør en ramme, som derfor ikke udelukkende kan forstås i relation til det tematiske niveau, men i lige så høj grad bør forstås gennem de æstetiske valg og strategier. Som sammenligningen af Dammas' film og Swiderskas bog med Koflers dokumentar har vist, er der en afgørende forskel i forhold til både det æstetiske og tematiske niveau, hvad enten man taler ud fra hukommelsens eller posthukommelsens perspektiv. Posthukommelse, som hos de omtalte kunstnere bogstaveligt talt er 'over grænser', kan betragtes som en fremstillingsstrategi for grænseoverskridelser i både tid, rum og æstetik.

The publication has been subsidized by the National Science Centre in Poland, no. DEC-20II/03/D/HS2/00785

\section{LITTERATURLISTE}

Agamben, Giorgio. Means without End. Notes on Politics, Minneapolis: University of Minnesota Press, 2000.

Adorno, Theodor W. "Kulturkritik und Gesellschaft". Prismen. Berlin und Frankfurt am Main: Suhrkamp Verlag, I955.

Ankersmit, Frank. "Pamiętając Holocaust: żałoba i melancholia”. Przeł. A. Ajschtet,

A. Kubis, J. Regulska. Frank Ankersmit. Narracja, reprezentacja, doświadczenie. Studia z teorii historiografii. Red. Ewa Domańska, Kraków: Universitas, 2004.

Arendt, Hannah. "We Refugees". Menorah Journal I (1943): 77. Altogether Elsewhere. Writers on Exile. Red. Marc Robinson. Boston and London: Faber and Faber, I994.

Ashcroft, Bill et al. Post-Colonial Studies. The Key Concepts, 2. udg. London and New York: Routledge, 2007.

Bakhtin, Mikhail. Rum, tid ๘ historie. Kronotopens former i europaisk litteratur. Oversat fra russisk af Harald Jepsen. Århus: Forlaget Klim, 2006.

Bal, Mieke (red.) with the assistance of Bryan Gonzales. The Practice of Cultural Analysis. Exposing Interdisciplinary Interpretation. Stanford: Stanford University Press, I999.

Beller, Manfred og Joep Leerssen (red.). Imagology. The Cultural Construction and Literary Representation of National Characters. A Critical Survey. Amsterdam - New York: Rodopi, 2007. Bondebjerg, Ib. Virkelighedens fortallinger. Den danske tv-dokumentarismes historie. Frederiksberg: Samfundslitteratur, 2008. 
Bukdahl, Lars. Tale ved tildelingen af (den ene halvdel af) Munch-Kristensens

Debutpris 2009 til Maja Magdalena Swiderska. Weekendavisen 9. oktober 2009.

Cresswell, Tim. Place. A short introduction. Malden MA: Blackwell, 2004.

Eyerman, Ron. Cultural Trauma. Slavery and the Formation of African American

Identity. Cambridge, New York: Cambridge University Press, 200I.

Harnow Klausen, Søren. "Hyggeligt, men lavt til loftet, eller er det plat at have det

godt?” Velfardsfortallinger. Om dansk litteratur i velfardsstatens tid. Red. Nils Gunder Hansen. København: Gyldendal, 20IO.

Hirsch, Marianne. Family Frames: Photography, Narrative and Postmemory. Cambridge: Harvard University Press, 1997.

Hirsch, Marianne og Irene Kacandes (red.). Teaching the Representation of the Holocaust. New York: The Modern Language Association of America, 2004.

Larsen, Svend Erik. Tekster uden granser. Litteratur og globalisering. Århus: Aarhus Universitetsforlag, 2007.

Larsen, Svend Erik. "'Lad os genskabe det, der er tæt på os, et sted langt fra os’. Det lokale mellem udelukkelse og integration”. Passage 54 (2005).

Mazierska, Ewa og Laura Rascaroli. Crossing New Europe. Postmodern Travel and the European Road Movie. London and New York: Wallflower Press, 2006.

Mellon, James. Og gamle Danmark - en beskrivelse af Danmark $i$ det herrens àr 1992. Oversat fra engelsk af Claes Johansen. Viby J.: Centrum, I992.

Mrozewicz, Anna. "Dokument i pamięć. Czego poszukuje Jacob Dammas - reżyser i bohater Kredensu?” Polskie kino dokumentalne przełomu wieków. Red. Katarzyna Mąka-Malatyńska, Mikołaj Jazdon. Poznań: Zamek, 20II.

Naficy, Hamid. An Accented Cinema. Exilic and Diasporic Filmmaking. Princeton: Princeton University Press, 200I.

Osęka, Piotr. Marzec '68. Kraków: Wydawnictwo Znak, 2008.

Ping Huang, Marianne. "Sjov og ballade for alvor”. Boganmeldelse af Maja Magdalena Swiderskas The Border Breaking Bunch. Information II. september 2008: I2.

Pollock, Griselda. "After the Reapers: Gleaning the Past, the Feminine and Another Future, from the Work of Bracha Lichtenberg Ettinger”. Bracha Lichtenberg Ettinger. Halal-Autistwork. Jerusalem: The Israel Museum 1995. Citeret fra: Głowacka, Dorota. "Świadkowie wbrew sobie: strategie pamięci Holokaustu w twórczości plastycznej kobiet 'drugiego pokolenia”. Obieg/Artmix. I9. Marts 20I4, http://www.obieg.pl/artmix/I4392.

Ringgaard, Dan. Stedssans. Århus: Aarhus Universitetsforlag, 2010.

Rushdie, Salman. Imaginary Homelands. Essays and Criticism I98I - I99I. London: Granta Books, I99I.

Van Alphen, Ernst. "Second-generation testimony, transmission of trauma, and postmemory". Poetics Today. 27.2 (2006).

Zeuthen, Louise. "Det private er politisk". Velfardsfortallinger. Om dansk litteratur $i$ velfardsstatens tid. Red. Nils Gunder Hansen. København: Gyldendal, 2010. 